\title{
Brand Analysis of Lazada Online Store Consumers in Padang City
}

\author{
Sepris Yonaldi ${ }^{1}$, Yuni Candra ${ }^{2}$, Edi Suandi ${ }^{3}$, Mairin Yuli Susinta ${ }^{4}$ \\ ${ }^{1}$ Department of Management, Faculty of Economics, Tamansiswa University, Padang \\ ${ }^{2}$ Department of Management, Faculty of Economics, Tamansiswa University, Padang \\ ${ }^{3}$ STES, Manna Wasalwa, Tanah Datar \\ ${ }^{4}$ Department of Management, Faculty of Economics, Tamansiswa University, Padang \\ (cc) EY
}

\begin{abstract}
This study aims to analyze the influence of brand experience and brand trust on brand satisfaction at Consumer Lazada online store in the city of Padang. This study uses a descriptive quantitative approach, and uses purposive sampling to draw data on 100 samples as respondents with survey techniques through Google form. To analyze data using path analysis. From the results of the $t$ test and the $F$ test conducted, it was found that brand experience and brand trust partially and simultaneously had a significant effect on brand satisfaction in the Lazada online store consumer store in Padang City.
\end{abstract}

Keyword- Brand Experience; Brand Trust; Brand Satisfaction; Lazada; Kota Padang

\section{INTRODUCTION}

Nowadays technology is increasingly developing, so anything that will be done depends on technology. Just how can users use and use it well. With the rapid development of electronic-based technology, it is increasingly increasing the growth of businesses using internet networks, which can cut distribution and marketing channels more effectively and efficiently.

(Yonaldi, 2018) explains that, e-commerce businesses today are growing very fast, even outperforming the conventional business sector. For example, the more sluggish the retail business, even some large retailers are already closed in Indonesia. Ecommerce is an online transaction or also can be a way of shopping, selling, or trading online or direct selling that utilizes internet facilities, where there are websites that can provide services (get and deliver).
E-commerce is growing rapidly in Indonesia, this can be seen from the increasing demand for consumers shopping for businesses that use the concept of ecommerce business models. Lazada online stor is one example of a company that successfully uses the business concept. Based on the latest study of the Ecommerce iPrice Map in the first quarter of 2018, Lazada is still able to maintain the top position as a marketplace with the most visitors, reaching 117.57 million visitors. While Tokopedia was second with 117.3 million visitors in the first three months of this year. Then Bukalapak followed with 53.59 million visitors (katadata.co.id, 2018). nlike the other online stores, lazada focuses on the type of B2C e-commerce (Business to Customer). Lazada greatly facilitates its customers in making transactions both transfer, COD (cash on delivery), credit cards, because Lazada has collaborated with various banks in Indonesia. 


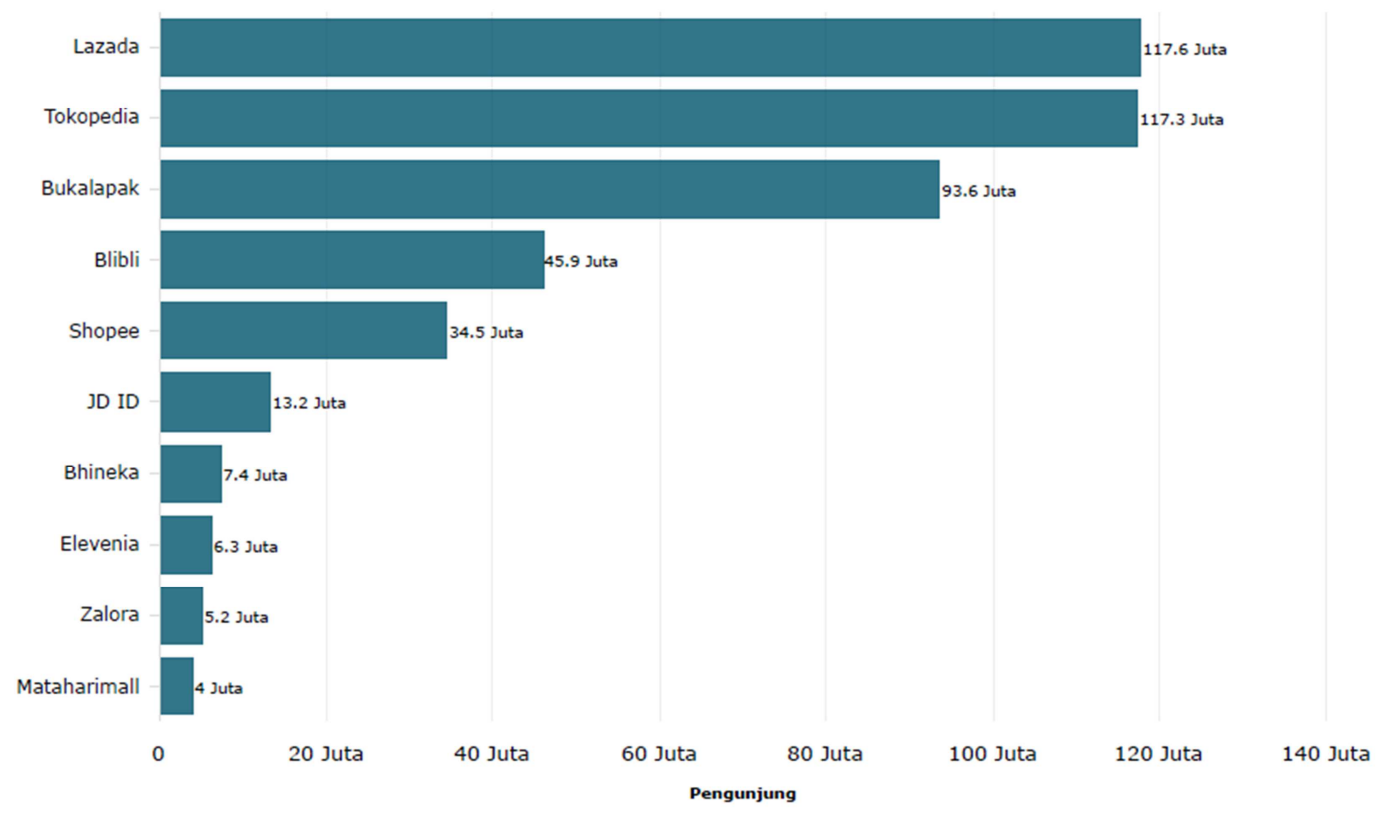

Figure 1. 10 e-Commerce with the Most TW1 2018 Visitors in Indonesia (https://databoks.katadata.co.id/datapublish/, 2018)

Brand Experience and Brand Trust are variables that can be used to explain the extent of customer satisfaction with a particular product. In marketing activities, product brand issues are very important to consider. In general, consumers tend to buy products with well-known brands based on their considerations. Brand satisfaction will be easier to form and companies will have brand names that have strong consumer loyalty.

According to Alloza (2008: 113) in (Carlos Bryan Sidabutar, 2015) brand experience is defined as consumer perceptions of each consumer relationship with the brand, to know the brand image was included in the advertisement, when the personal contact with the brand, or the level of quality regarding the personal treatment they received from the brand.

In order a product to provide maximum emotional benefits to consumers, the product must have the characteristics or uniqueness that distinguishes it from its competitors. The key is to create a brand experience.
Brakus et al. (2009: 224) in (I Gede Putu Pranadata, 2017) conduct research related to brand experience by looking at it from the consumer's point of view by testing the experience of the consumer that results in attitudes, and other aspects of consumer behavior related to products or services. Brand experience can be felt directly and also indirectly by consumers. Consumers will feel brand experience directly after consumers consume the products or services offered by the brand, while consumers feel brand experience indirectly when consumers see advertisements or other marketing strategies carried out by the brand related to their products or services offer.

According to Brakus et al. (2009: 224) in (Hatane Semuel, 2018) there are 4 dimensions of brand experience:

1. Sensory is creating experience through vision, sound, touch, smell, and taste.

2. Affection is an approach to feeling by influencing moods, feelings and emotions. 
3. Behavior is creating physical experiences, behavioral patterns, lifestyles.

4. Intellectuals are creating experiences that encourage consumers to be involved in careful thinking about the existence of a brand

According to (Keller, 1993) states that brand trust is a comfortable feeling that is owned by product users based on consumer perceptions of the product brand that raises consumer confidence and pay attention to the interests and welfare of consumers.

According to (Petter, 2009) brand trust is an expectation or desire for excellence and intense brand on products / goods or services and brand trust reflects two things namely brand reliability and brand intention. Brand reliability, this is based on what consumers believe in products / goods or services that are able to meet the promised value that the brand is able to meet the needs and provide satisfaction to consumers. And brand intention, this is based on what consumers believe in the brand to be able to prioritize the interests of consumers when problems in the use of products / goods or services that appear unexpectedly.

1so, Reast (2003) in (Reast, 2005) conducting UK research on real and fictitious brands within low involvement products and services categories, finds that brands with higher trust ratings tended to have significantly higher brand extension ratings for line, related and unrelated extension concepts, relative to same category lower trust rated rivals.

According to Kustini (2011: 23) in (Mohammad Rizan, 12) brand trust can be measured through the dimensions of viability (dimension of viability) and dimensions of intentionality (dimension of intentionality).

1. Dimension of Viability This dimension represents a perception that a brand can meet and satisfy consumer needs and values. This dimension can be measured through indicators of satisfaction and value.

2. Dimension of Intentionality, this dimension reflects the feeling of security of an individual towards a brand. This dimension can be measured through security and trust indicators.

According to Delgado in (Ferrinadewi, 2008, p. 155) there are two indicators that influence brand trust.

\section{Brand Reliability}

Brand Reliability is the will of the brand that comes from consumer confidence in the product is able to fulfill the promised value or in other words the perception that the value is able to meet needs and provide satisfaction.

\section{Brand Intension}

Brand Intension or interest in the brand reflects consumer confidence that the brand is able to prioritize the interests of consumers when problems in product consumption appear unexpectedly. Therefore, intentionality is related to the belief that brands will be interested in what consumers need and will not take advantage of consumers' ignorance.

Customer satisfaction on the brand is a customer response to the quality of an actual product and expectations that the customer wants after the customer consumes it (Caruana, 2002). According to Durianto et al. (2001, p. 19), Satisfaction is a direct measurement of how customers remain loyal to a brand. Satisfaction is primarily a primary measurement where the needs and desires of consumers for a product can be fulfilled (Kusuma, 2014, p. 2).

According to Fullerton (1990: 6) in (Kusuma, 2014, p. 2) brand satisfaction is measured using 3 indicators, namely:

1. Satisfaction on the product

2. Brand satisfaction

3. Fun for the product 


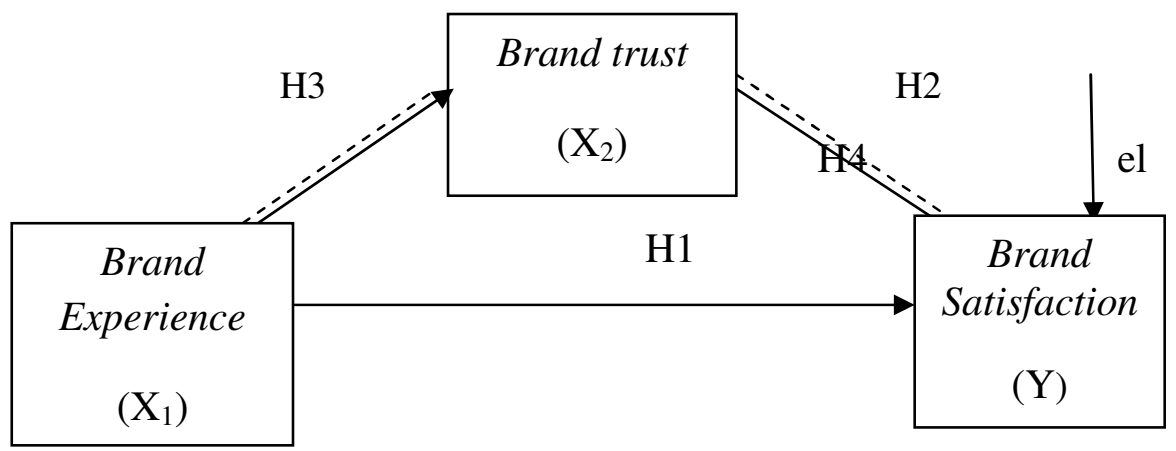

Figure 2. Kerangka Konseptual Penelitian

The objectives of this study are as follows:

1. To know and analyze the influence of brand experience on brand satisfaction on Lazada in the city of Padang.

2. To know and analyze the influence of brand trust on brand satisfaction on Lazada in the city of Padang.

3. To know and analyze the influence of brand experience on brand trust in Lazada in the city of Padang.

4. To know and analyze the influence of brand experience through brand trust on brand satisfation in Lazada in the city of Padang

\section{RESEARCH METHODS}

To find out whether or not there is an influence of brand experience (X1) and brand trust (X2) on brand satisfaction (Y) partially and simultaneously and to know the effect of brand experience through brand trust on brand satisfaction in Lazada in Padang city, then this study uses a quantitative approach descriptive, and using purposive sampling to draw data on 100 samples as respondents with survey techniques through Google form. To analyze the data of researchers using path analysis.

\section{RESUlt AND DiscuSSION}

Effect of Brand Experience on Brand Satisfaction at Lazada Online Store in Padang City. Based on the testing of the path coefficient hypothesis on the brand experience variable, the results showed that the effect of brand experience (X1) on brand satisfaction $(\mathrm{Y})$ on the Lazada online store in Kota Padang was pX1Y = 0.588 . The effect of brand experience (X1) on brand satisfaction $(\mathrm{Y})$ is $0.5882=0.3457$ or $34.57 \%$. At a significance level of 0.00 which can be interpreted as significant because it is below 0.05 . So it can be concluded that brand experience has a significant effect on brand satisfaction on Lazada online store in Padang City.

The Effect of Brand Trust on Brand Satisfaction on Lazada Online Store in the City of Padang. Based on the testing of the path coefficient hypothesis on the brand trust variable, the results show that the effect of brand trust $(\mathrm{X} 2)$ on brand satisfaction $(\mathrm{Y})$ on the Lazada online store in Padang City is $\mathrm{pX} 2 \mathrm{Y}=0.325$. The influence of brand trust (X2) on brand satisfaction (Y) is $0.3252=0.1056$ or $10.56 \%$. At a significance level of 0.00 , which means smaller than 0.05 ? So that it can be concluded that brand trust has a significant effect on brand satisfaction on Lazada online store in Padang City.

The Influence of Brand Experience through Brand Trust against Brand Satisfaction at Lazada Online Store in the City of Padang. Based on the testing of the path coefficient hypothesis, it was found that the effect of brand experience (X1) through brand trust (X2) on brand satisfaction (Y) on Lazada online store in Padang City was 0.0745 , obtained from the results of pYX1. rX1X2. pYX2 $=0.588 .0 .789 .0 .325=0.1507$ with a percentage of $15.07 \%$. At a significance level of 
0.00 , which means smaller than 0.05 ? So that it can be concluded that the brand experience variable (X1) through brand trust (X2) has a significant effect on brand satisfaction $(\mathrm{Y})$ on Lazada online store in Padang City.

\section{CONCLUSION}

Based on the path analysis of brand experience and brand trust variables on brand satisfaction on Lazada online store in Padang City, get $\mathrm{Y}=0.588 \mathrm{X} 1+$ $0.325 \mathrm{X} 2+0.2469$ e. From the results of the $t$ test, it was found that brand experience and brand trust partially had a significant effect on brand satisfaction on Lazada online store in Padang City. The F test results proved that brand experience and brand trust variables simultaneously had a significant effect on brand satisfaction on Lazada online store in Padang City. From the results of the determinant coefficient, the adjusted $\mathrm{R}$ square value is $74.8 \%$ of brand experience and brand trust together influences brand satisfaction, while $25.2 \%$ is influenced by other variables not discussed in this study. the brand experience variable (X1) through brand trust (X2) has a significant effect on brand satisfaction $(\mathrm{Y})$ on Lazada online store in Padang City.

\section{REFERENCES}

[1] Carlos Bryan Sidabutar, D. D. (2015). Analisa Pengaruh Brand Experience Terhadap Customer Loyalty Melalui. Jurnal Manajemen Pemasaran Petra , 1 (1), 4.

[2] Ferrinadewi, E. (2008). Merek dan psikologi konsumen. Yogyakarta: Graha Ilmu.

[3] Hatane Semuel, R. S. (2018). Brand Experience, Brand Commitment, Dan Brand. Jurnal Manajemen Pemasaran, 12 (2), 70.

[4] I Gede Putu Pranadata, M. R. (2017). Analisis Pengaruh Brand Experience Terhadap Brand Perceived Value, Brand Satisfaction, Dan Brand Loyalty. Jurnal Bisnis dan Manajemen , 4 (2), 220.

[5] katadata.co.id. (2018, April 18). Lazada, eCommerce Paling Banyak Pengunjung TW I 2018. Retrieved April 24, 2019, from katadata.co.id:

https://databoks.katadata.co.id/datapublish/2018/0

4/18/lazada-e-commerce-paling-banyak-

pengunjung-tw-i-2018

[6] Keller, L. K. (1993). Conceptualizing, Measuring, and Managing Customer-Based. Journal of Marketing , 57 (1), 1-22.

[7] Mohammad Rizan, B. S. (12). Pengaruh Brand Image Dan Brand Trust Terhadap Brand Loyalty Teh Botol Sosro. Jurnal Riset Manajemen Sains Indonesia (JRMSI) , 3 (1), 5.

[8] Petter, P. J. (2009). Consumer Behavior \& Marketng Strategy (9 ed.). McGraw-HillIrwin: Irwin.

[9] Reast, J. D. (2005). Brand trust and brand extension acceptance: the relationship. Journal of Product \& Brand Management, 14 (1), 4.

[10] Yonaldi, S. (2018). Kewirausahaan Menumbuhkembangkan UMKM di Era Digital. (B. B. Hafrizal Okta Ade Putra, Ed.) Padang, Sumatera Barat, Indonesia: PT. Brain Insight Indonesia [BRIGHT]. 